\title{
Soil respiration patterns and controls in limestone cedar glades
}

\author{
Jennifer Cartwright • Dafeng Hui
}

Received: 27 March 2014 / Accepted: 28 November 2014 / Published online: 7 December 2014

(C) The Author(s) 2014. This article is published with open access at Springerlink.com

\begin{abstract}
Aims Drivers of soil respiration $\left(R_{S}\right)$ in rock outcrop ecosystems remain poorly understood. We investigated these drivers in limestone cedar glades, known for their concentrations of endemic plant species and for seasonal hydrologic extremes (xeric and saturated conditions), and compared our findings to those in temperate grasslands and semi-arid ecosystems.

Methods We measured $R_{s}$, soil temperature $\left(T_{s}\right)$, volumetric soil water content (SWC), soil organic matter (SOM), soil depth, and vegetation cover monthly over 16 mo and analyzed effects of these variables on $R_{s}$.

Results Seasonally, $R_{S}$ primarily tracked $T_{S}\left(\mathrm{r}^{2}=0.77\right.$; $P<0.01$ ), however $R_{s}$ was depressed during a summer drought. SOM was highly variable spatially, and incorporating SOM effects into the $R_{s}$ model dramatically improved model performance. Both shallow soil and sparse vegetation cover were also associated with lower $R_{s}$.

Conclusions Soil depth, SOM, and vegetation cover were important drivers of $R_{S}$ in limestone cedar glades.

Responsible Editor: Eric Paterson.

J. Cartwright $(\square)$

U.S. Geological Survey,

Lower Mississippi-Gulf Water Science Center,

640 Grassmere Park, Suite 100, Nashville, TN 37211, USA

e-mail: jmcart@usgs.gov

D. Hui

Department of Biological Sciences,

Tennessee State University,

Nashville, TN 37209, USA

e-mail: dhui@tnstate.edu
\end{abstract}

Seasonal $R_{s}$ patterns reflected those for mesic temperate grasslands more than for semi-arid ecosystems, in that $R_{s}$ primarily tracked temperature for most of the year.

Keywords Limestone cedar glades · Rock outcrop ecosystems $\cdot$ Soil depth $\cdot$ Soil organic matter $\cdot$ Soil moisture $\cdot$ Soil respiration
Abbreviations
$R_{S} \quad$ Soil respiration
$T_{S} \quad$ Soil temperature
AIC Akaike Information Criterion
NPS National Park Service
SOM Soil Organic Matter
SWC Volumetric Soil Water Content
TDR Time Domain Reflectometry

\section{Introduction}

Soil respiration $\left(R_{S}\right)$ in terrestrial ecosystems is the primary means of carbon transfer to the atmosphere and is the most important carbon flux other than gross primary productivity (Dixon et al. 1994; Schimel 1995). Rates and controls of $R_{S}$ are highly variable across ecosystems and across a range of spatial and temporal scales (Luo et al. 2001; Hui and Luo 2004; Bond-Lamberty and Thomson 2010). Although the biotic and abiotic controls on $R_{S}$ have been extensively investigated across many of Earth's major ecosystems (Liu et al. 2002; Luo and Zhou 2006; Subke et al. 2006; Deng et al. 2012), 
these controls remain unstudied in certain rock outcrop ecosystems, such as limestone cedar glades (Quarterman 1950a; Baskin and Baskin 1999). The abiotic stress regime in limestone cedar glades is characterized by very thin soils (Baskin and Baskin 2003; Baskin et al. 2007a), widely fluctuating hydrologic conditions (Quarterman 1950b; Norton 2010), and ground surface temperatures as high as $50{ }^{\circ} \mathrm{C}$ during the growing season in zones lacking canopy coverage (Freeman 1933; Baskin and Baskin 1999). Although the roles of these stressors in maintaining high densities of rare, endemic, and biogeographically disjunct plant taxa have been explored (Baskin and Baskin 1985; 1988; 1989), no studies have been conducted on their effects on $R_{s}$.

Limestone cedar glades share some aspects of abiotic stress regime, landscape physiognomy, and vegetation composition with temperate mesic grasslands and semiarid ecosystems (Quarterman 1989; Quarterman et al. 1993; Jarvis et al. 2007). In temperate mesic grasslands, $R_{S}$ is controlled primarily by soil temperature $\left(T_{S}\right)$ and soil water content (SWC) (Kucera and Kirkham 1971; Mielnick and Dugas 2000), and is also influenced by vegetation cover, soil thickness, topographic position on the landscape, soil organic matter content (SOM), and soil carbon content (Bremer et al. 1998; Craine and Wedin 2002; Flanagan and Johnson 2005; Risch and Frank 2006; Thomson et al. 2010; Craine and Gelderman 2011). Cedar glades fit standard definitions as grasslands (Noss 2013), since their vegetation is predominantly herbaceous with sparse shrub and tree cover (Baskin and Baskin 1999; Baskin et al. 2007b). However, they have shallower soils, more exposed bedrock, and different plant community composition than do prairies or savannas (Anderson et al. 1999; Lawless et al. 2006; Baskin et al. 2007a).

Cedar glade vegetation has constituents adapted to seasonally xeric soil conditions-e.g. succulents, crassulacean acid metabolism (CAM) species — suggesting a similarity to arid or semi-arid ecosystems (Quarterman 1950a; Baskin et al. 1995; Norton 2010). In ecosystems such as deserts, semi-arid steppes, and Mediterranean ecosystems, soil moisture limitations are especially important controls on $R_{S}$ (Amundson et al. 1989; Reichstein et al. 2002; Jia et al. 2006; Zhang et al. 2009; Talmon et al. 2011). Precipitation-triggered $\mathrm{CO}_{2}$ efflux pulses often contribute substantially to seasonal and annual efflux totals (Xu et al. 2004; Tang and Baldocchi 2005; Jarvis et al. 2007; Vargas and Allen 2008; Munson et al. 2009), highlighting the importance of precipitation timing and antecedent soil moisture conditions (Schwinning et al. 2004; Rey et al. 2005; Jarvis et al. 2007; Sponseller 2007; Cable et al. 2008, 2013; Shen et al. 2008; Munson et al. 2009). In contrast to mesic ecosystems, xeric soil conditions commonly suppress $R_{S}$ on a seasonal basis despite favorable temperatures, such that the $R_{S}$ response to $T_{S}$ varies based on soil moisture conditions (Rey et al. 2002; Joffre et al. 2003; Xu et al. 2004; Almagro et al. 2009; Liu et al. 2009; Carbone et al. 2011; Rey et al. 2011). $R_{S}$ in arid and semi-arid ecosystems is also influenced by vegetation cover (Maestre and Cortina 2003; Tang and Baldocchi 2005; Vargas and Allen 2008; Cable et al. 2008; Almagro et al. 2009) and soil organic carbon pools (Conant et al. 2000; Sponseller 2007; Talmon et al. 2011; Balogh et al. 2011), and by their interactive effects with temperature and moisture (Wildung et al. 1975).

In contrast to many arid and semi-arid ecosystems, cedar glades commonly contain microhabitats that are seasonally saturated or inundated as well as seasonally xeric (Quarterman 1950b; Nordman 2004; Norton 2010). Also, seasonally xeric soil conditions in cedar glades are produced primarily by edaphic rather than climatic factors: although the timing and magnitude of precipitation are comparable to those of surrounding mesic forests, cedar glade soils experience more intense summer drying due to their shallowness and insolation (Quarterman 1950b; Martin and Sharp 1983; Baskin and Baskin 1999).

In this study, we investigated relationships between $R_{S}$ and known elements of the abiotic stress regime of limestone cedar glades (e.g. shallow soil, seasonal extremes in SWC, and seasonally high $T_{s}$ ). We also analyzed the effects of SOM and vegetation cover, biotic factors known to influence $R_{S}$ in temperate grasslands and in arid and semi-arid ecosystems. Our primary objectives were to: (1) determine whether temperatureand moisture-based $R_{s}$ models could be improved by incorporating SOM effects, and (2) assess differences in $R_{S}$ based on spatial variability in soil depth and vegetation cover.

\section{Materials and methods}

Study site

Field investigations were conducted at Stones River National Battlefield near Murfreesboro, Tennessee 
$\left(35^{\circ} 52^{\prime} 35^{\prime \prime} \mathrm{N}, 86^{\circ} 25^{\prime} 58^{\prime \prime} \mathrm{W}\right)$, USA, a 120 -acre federally-managed park that consists mostly of red cedar (Juniperus virginiana) and oak (Quercus spp.) forest in which several dozen limestone cedar glades are interspersed, on outcrops of thin-bedded, fine-grained Ordovician limestone (Mahr and Mathis 1981; Morris et al. 2002; Adams et al. 2012). Limestone cedar glades are a calcareous rock outcrop ecosystem present in the Interior Low Plateau, Appalachian Plateau, and Ridge and Valley physiographic provinces of the Southeastern United States (Fenneman 1938; Baskin and Baskin 1999). They contain edaphic climax communities in which succession is constrained by shallow soil (Quarterman 1950b; Baskin and Baskin 2003; Baskin et al. 2007b). Vascular plant density exhibits high spatial variability, ranging from sparsely vegetated areas of exposed bedrock to thickly vegetated glade-shrub communities in areas with deeper soil (see Figs. 2-8 in Quarterman 1950a; Nordman 2004).

Dominant vegetation includes $\mathrm{C}_{4}$ summer annual grasses, $\mathrm{C}_{3}$ forbs, mosses, cyanobacteria, and lichens, with generally sparse woody cover (Quarterman 1950a; Baskin and Baskin 1999; Baskin et al. 2007b). Characteristic plant taxa at this site include (graminoids) Andropogon gyrans, A. ternarius, A. virginicus, Sorghastrum nutans, and Sporobolus vaginiflorus; (forbs) Croton monanthogynus, Dalea gattingeri, Erigeron strigosus, Leavenworthia spp., Ruellia humilis, Sedum pulchellum, and Talinum calcaricum; and (shrubs) J. virginiana, Forestiera ligustrina, and Frangula caroliniana (Baskin and Baskin 1999; 2003; Nordman 2004). Cedar glades at this site also support the globally rare Astragalus bibullatus, A. tennesseensis, and Echinacea tennesseensis (Nordman 2004). The macroclimate of the region is humid and mesothermal (Baskin and Baskin 1999). The mean annual temperature is $12.2^{\circ} \mathrm{C}$, with monthly mean temperatures ranging from -3.2 to $32.6^{\circ} \mathrm{C}$. Monthly precipitation averages $12.4 \mathrm{~cm}$ and ranges from $4.0 \mathrm{~cm}$ to $17.1 \mathrm{~cm}$ (National Climatic Data Center 2014).

\section{Sampling design}

We established 36 quadrats, each measuring $0.5-\mathrm{m} \times$ $0.5-\mathrm{m}$, in 12 cedar glades. Roughly $80 \%$ (28 quadrats) were located within the glades, generally within zones of gravel pavement and graminoids, forbs, and moss. Roughly $20 \%$ (8 quadrats) were situated within a 3-m buffer of J. virginiana shrubland / forest immediately surrounding the glades. Quadrat locations within glades and within J. virginiana buffers were randomly assigned using ArcGIS version 9.3 (Esri, Redlands, CA, USA). Sampling was conducted monthly for 16 months (February 2012 through May 2013) following a rotational schedule, such that each quadrat was sampled four times at roughly four month intervals.

Environmental measurements

Soil depth (depth to bedrock; mean of four measurements per quadrat) was measured using a $1-\mathrm{cm}$ diameter metal probe inserted as far down into the soil as possible. $T_{S}$ (mean of three measurements per quadrat) was measured at 4-cm soil depth using a Taylor $9842 \mathrm{~N}$ waterproof digital thermometer (Taylor Inc., Oak Brook, IL, USA). Ground surface temperature (one measurement per quadrat) was measured using a Lloyd and Taylor 1994 indoor/outdoor digital thermometer and hygrometer (Taylor Inc., Oak Brook, IL, USA). SOM was estimated according to the loss-on-ignition method (Davies 1973) using soil samples obtained at 4-cm depth. For quadrats in which soil depth was less than $4 \mathrm{~cm}, T_{S}$ measurements and SOM estimations (at 4-cm depth) were performed as close to the quadrat as possible.

SWC was measured using time-domain reflectometry (TDR) probes (FieldScout TDR 300, Spectrum Technologies, Inc., Plainfield, IL, USA), fitted with $3.8 \mathrm{~cm}$ rods, where soil was sufficiently deep (at least two soil depth measurements within the quadrat were greater than $4 \mathrm{~cm}$ ), or otherwise by oven-drying performed according to Topp and Ferre (2002). Six TDR measurements or three oven-drying samples were taken per quadrat. Gravimetric soil water content was converted to volumetric equivalents using soil bulk density based on measured soil-core volume.

To establish a relationship between TDR and ovendrying measurement methods, an independent sample of 48 measurements, each conducted by both methods, was collected in November 2011, January 2013 and May 2013, within the same cedar glades used for monthly SWC observations. These paired measurements ranged from less than $8 \%$ to greater than $50 \%$ SWC, and were used to establish a natural log regression relationship $\left(\mathrm{r}^{2}=0.95, P<0.01\right)$ :

$\operatorname{In}\left(\mathrm{SWC}_{\mathrm{OD}}\right)=1.6881\left(\operatorname{In}\left(\mathrm{SWC}_{\mathrm{TDR}}\right)\right)-2.7187$ 
where $\mathrm{SWC}_{\mathrm{OD}}$ is the volumetric soil water content calculated from bulk density and gravimetric soil water content as measured by oven drying (expressed as percent dry weight) and $\mathrm{SWC}_{\mathrm{TDR}}$ is the volumetric soil water content measured by TDR (expressed as volumetric percent).

The quadrat percentage of graminoids, forbs, vines and shrubs - a rough classification of vascular plants following Cofer et al. (2008) - was estimated at each point based on visual examination, and categorized as "none," "less than $30 \%, "$, 30 to $70 \%$," or "greater than $70 \%$ " with scores assigned from 0 to 3 , respectively. The sum of these individual scores by vegetation type was calculated as an overall vegetation score for each quadrat.

Field measurements of in situ $R_{S}$ were obtained using a Li-Cor Infrared Gas Analyzer, LI-6400 XT Portable Photosynthesis System (Li-Cor Inc., Lincoln, NE, USA), fitted with a soil chamber attachment. At least 48 hours prior to the first $R_{S}$ measurement, three soil collars were inserted into the soil surface at each quadrat and the height of each collar above the soil surface was measured. Two measurement cycles were completed at each collar, yielding six $R_{S}$ measurements per quadrat.

Evaluation of soil respiration models

To explore the relationships between $R_{S}\left(\mathrm{CO}_{2}\right.$ efflux in $\left.\mu \mathrm{mol} \mathrm{m}{ }^{-2} \mathrm{~s}^{-1}\right)$ and $T_{s}$ (soil temperature in $\left.{ }^{\circ} \mathrm{C}\right), \operatorname{SWC}(\%$ volumetric soil water content), and SOM (\% loss on ignition), scatter plots were constructed of $R_{S}$ with these variables (Fig. 1). Based on these potential relationships, four models were tested:

Model $1: \mathrm{R}_{\mathrm{s}}=a e^{b T_{s}}$

Model 2: $\mathrm{R}_{\mathrm{s}}=a e^{b T_{s}}\left(c^{\mathrm{SWC}}\right)$

Model 3: $\mathrm{R}_{\mathrm{s}}=a e^{b T s}(\mathrm{SWC}-0.03)(0.6-\mathrm{SWC})^{c}$

Model 4: $\mathrm{R}_{\mathrm{s}}=a e^{b T_{s}}\left(C^{\mathrm{SWC}}\right)\left(\mathrm{SOM}^{d}\right)$

In Model 1, $R_{S}$ was exponentially related to $T_{S}$ (Kucera and Kirkham 1971; Luo et al. 2001; Rey et al. 2002; Fig. 1a). Model 2 incorporated SWC as an exponential function (Fig. 1b). Model 3 used observed upper and lower bounds on SWC and predicted highest $R_{S}$ at intermediate SWC values (Davidson et al. 1998; Moyano et al. 2013; Fig. 1c). Model 4 was based on Model 2, and incorporated SOM as a power function (Fig. 1d). For all models, SWC was expressed as a decimal and $a, b, c$, and $d$ were fitted model parameters, with $a$ representing the basal respiration rate at a temperature of $0{ }^{\circ} \mathrm{C}$, and $b, c$, and $d$ representing the effects on $R_{S}$ of $T_{S}$, SWC, and SOM, respectively. The increase in $R_{S}$ for a $10{ }^{\circ} \mathrm{C}$ temperature increase $\left(\mathrm{Q}_{10}\right.$, temperature sensitivity) was calculated as:

$\mathrm{Q}_{10}=e^{10 b}$

The criteria for model selection were: (1) Akaike Information Criterion (AIC), (2) comparison of $\mathrm{r}^{2}$ values, and (3) evaluation of model residuals. AIC was used as a penalized likelihood criterion:

$\mathrm{AIC}=-2 \ln (\mathrm{L})+2 \mathrm{p}$

where $\mathrm{L}$ is the likelihood of the fitted model and $\mathrm{p}$ is the number of parameters in the model (Burnham and Anderson 2002). Following model evaluation based on minimized AIC value, model selection was confirmed based on maximized $r^{2}$ value, lack of correlation between model residuals and explanatory variables, and a Wald-Wolfowitz runs test for randomness of the model residuals (Motulsky and Ransnas 1987).

Statistical analysis

All analyses were performed using SAS 9.3 (SAS Institute, Cary, NC, USA). Comparison of $R_{S}$ across soil moisture categories (SWC below $15 \%$, between 15 and $40 \%$, and above $40 \%$ ) was performed using ANOVA and a Tukey's post hoc test. To detect whether these differences existed independently from temperature effects, the same analysis was performed using residuals from Models 1 and 4. Parameter estimates for Model 4 were compared across soil moisture categories using a Student's $t$-test.

Relationships between $R_{S}$ and soil depth and between $R_{S}$ and vegetation cover were evaluated using ANOVA and a Tukey's post hoc test across three soil depth classes: shallow (soil depth less than $5 \mathrm{~cm}, n=33$ ), moderate ( 5 to $10 \mathrm{~cm}, n=58$ ) and deep (greater than $10 \mathrm{~cm}, \mathrm{n}=31$ ); and across three vegetation cover classes: 

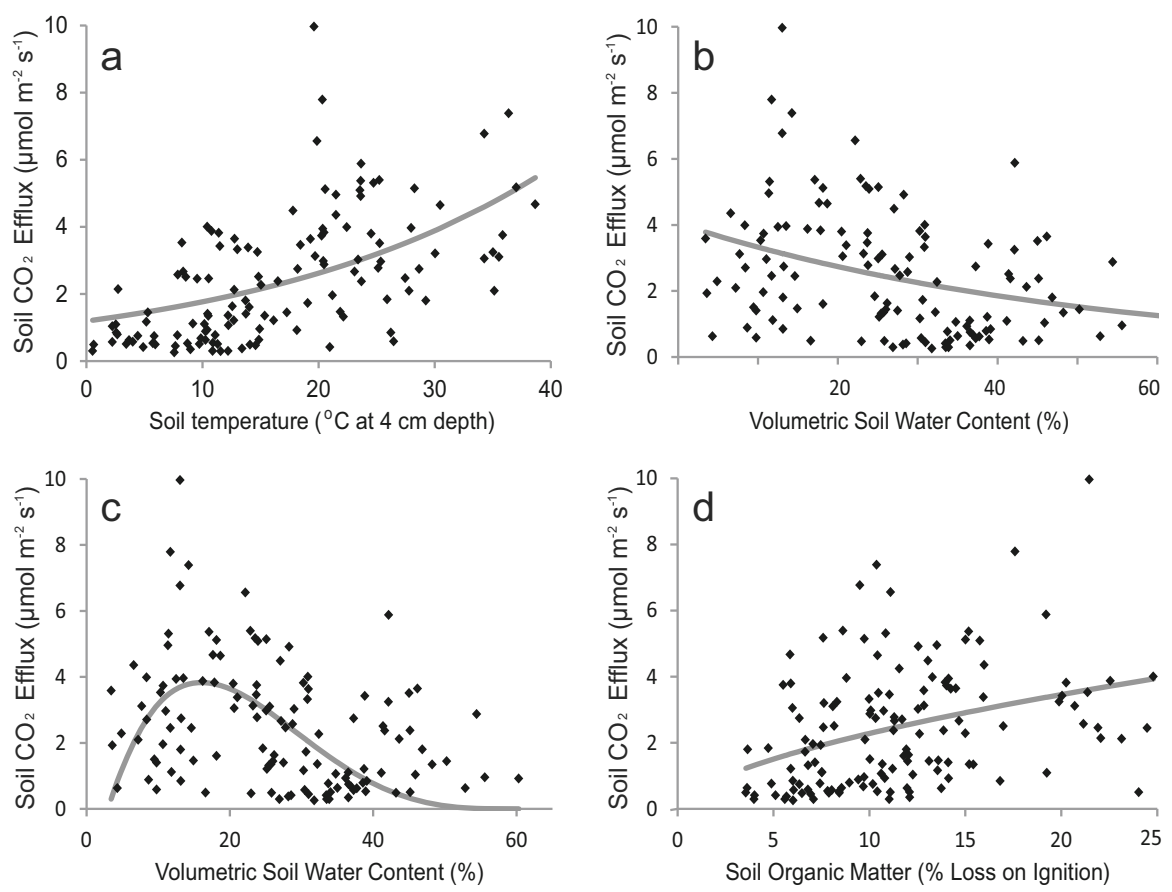

Fig. 1 Modelled relationships between soil respiration rates and model variables: (a) soil temperature (Model 1); (b) the soil water content relationship in Model 2; (c) the soil water content relationship in Model 3; and (d) the soil organic matter relationship in Model 4

sparse (vegetation score of 1 or $2, n=63$ ), moderate ( 3 to $4, n=40$ ), and dense (score above $4, n=19$ ). To detect differences in $R_{s}$ related to soil depth and vegetation cover after having accounted for $T_{s}$, SWC, and SOM, the same analysis was conducted using Model 4 residuals.

\section{Results}

Seasonal patterns of soil temperature, moisture, and respiration

Over the 16 months of the study period, ground surface temperatures (means across sampling locations) ranged from $3.7{ }^{\circ} \mathrm{C}$ in January 2013 to $41.9^{\circ} \mathrm{C}$ in June 2012 (Fig. 2a), and mean $T_{s}$ at 4$\mathrm{cm}$ soil depth ranged from $2.6^{\circ} \mathrm{C}$ in January 2013 to $30.6{ }^{\circ} \mathrm{C}$ in July 2012. The annual mean (February 2012 through January 2013) was $25.3^{\circ} \mathrm{C}$ for ground surface temperature and $17.6{ }^{\circ} \mathrm{C}$ for $T_{s}$ at $4-\mathrm{cm}$ soil depth. Consistent with previous observations in limestone cedar glades (e.g. Quarterman 1950b; Norton 2010), hydrologic conditions seasonally ranged from xeric (the minimum SWC measured at a particular sampling location was less than $3.5 \%$ in June 2012) to visibly saturated (individual observations of SWC greater than $50 \%$ in December 2012, March 2013 and May 2013). Mean SWC across sampling locations ranged from $6.1 \%$ in June 2012 to $43.5 \%$ in March 2013, with an annual mean of $23.0 \%$ (Fig. 2b). Soil moisture was generally lowest in the summer and autumn (with the exception of July), and higher in the winter and early spring. Reflecting these seasonal patterns, SWC was inversely correlated with ground surface temperature $\left(\mathrm{r}^{2}=0.47 ; P<0.05\right)$ and with $T_{S}\left(\mathrm{r}^{2}=0.35 ; P<0.05\right)$.

Mean $R_{S}$ rates across sampling locations ranged from $0.7 \mu \mathrm{mol} \mathrm{m} \mathrm{m}^{-2} \mathrm{~s}^{-1}$ in December 2012 to $5.3 \mu \mathrm{mol} \mathrm{m}^{-2} \mathrm{~s}^{-1}$ in August 2012, with an annual mean of $2.7 \mu \mathrm{mol} \mathrm{m} \mathrm{s}^{-2}$ (Fig. 2c). We estimated an overall $\mathrm{Q}_{10}$ value of 2.01. Seasonally, $R_{S}$ was strongly positively correlated with ground surface temperature $\left(\mathrm{r}^{2}=0.81\right.$; $P<0.01)$ and $T_{s}\left(\mathrm{r}^{2}=0.77 ; P<0.01\right)$ and was inversely correlated with SWC $\left(\mathrm{r}^{2}=0.50 ; P<0.01\right)$. Both $R_{S}$ and ground surface temperature were relatively high during the summer, declined throughout the autumn, remained low over the winter and began to rise again during the spring (Figs. 2a and c). From May through September 2012, mean ground surface temperatures above $30^{\circ} \mathrm{C}$ were observed along with mean $R_{S}$ rates above $3.0 \mu \mathrm{mol} \mathrm{m} \mathrm{m}^{-2} \mathrm{~s}^{-1}$, except for the field visit in late June 
Fig. 2 Seasonal patterns of (a) ground surface temperature, (b) volumetric soil water content, and (c) soil $\mathrm{CO}_{2}$ efflux from February 2012 to May 2013 (squares indicate means across all sampling locations; error bars indicate one standard error)
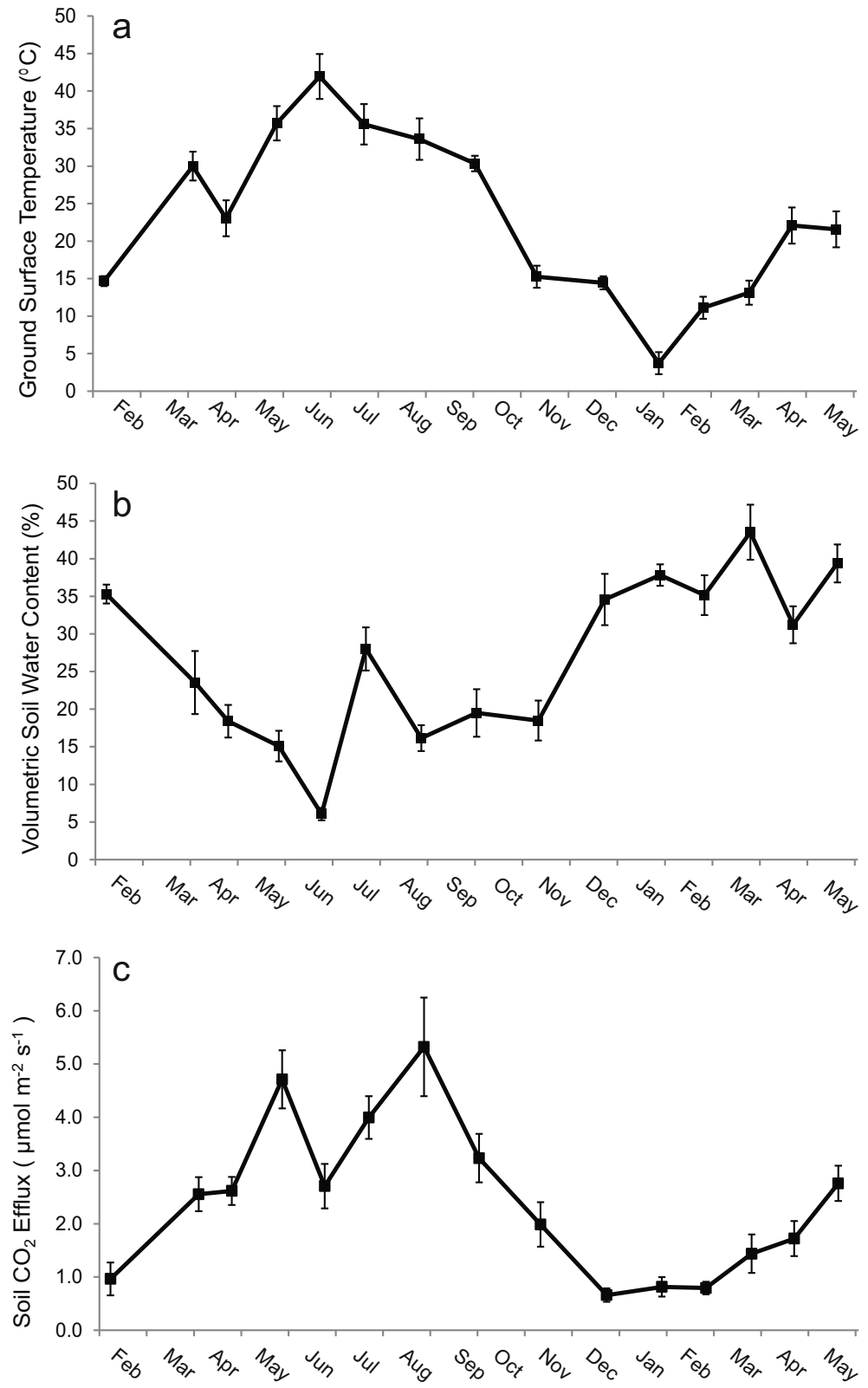

for which a dip in mean $R_{S}$ rate (to $2.7 \mu \mathrm{mol} \mathrm{m} \mathrm{m}^{-2} \mathrm{~s}^{-1}$ ) coincided with extremely dry soil conditions (mean SWC of $6.1 \%$ ) toward the end of a drought lasting several weeks. Under relatively dry soil conditions for this site (SWC less than $15 \%$ ), the temperature effect on $R_{S}$ was significantly greater $(b=0.09)$ than when SWC was greater than $15 \%(b=0.06) ; \mathrm{t}(113)=2.25, P<0.05$. Rates of $R_{S}$ were significantly higher $(P<0.05)$ when SWC was less than $15 \%$ (mean $3.50 \mu \mathrm{mol} \mathrm{m} \mathrm{m}^{-2} \mathrm{~s}^{-1}$ ) as compared to SWC ranging between $15 \%$ and $40 \%$ (mean $2.25 \mu \mathrm{mol} \mathrm{m} \mathrm{m}^{-2}$ ) or when SWC was greater than $40 \%$ (mean $2.04 \mu \mathrm{mol} \mathrm{m}{ }^{-2} \mathrm{~s}^{-1}$ ). After accounting for temperature effects using Model 1 and Model 4 residuals, however, these differences were not significant $(P>0.05)$, indicating that differences in $R_{S}$ across these soil moisture categories did not exist independently from temperature effects.

Evaluation of soil respiration models

Model 4 was selected as the best model based on minimized AIC value (Table 1). Additionally, Model 4 had 
the highest $\mathrm{r}^{2}$ value and was the only model that did not deviate systematically from the data based on a WaldWolfowitz runs test for randomness of the model residuals (Motulsky and Ransnas 1987). Of the models that incorporated SWC (Models 2 through 4), only Model 4 had model residuals that were uncorrelated with all explanatory variables. Based on AIC value, $\mathrm{r}^{2}$ value, and residuals analysis, incorporating SWC (Models 2 and 3) improved model performance only marginally as compared to the temperature-only model (Model 1). Based on the same criteria, however, incorporation of SOM effects (Model 4) dramatically improved model performance. Several other models incorporating $T_{s}$, SOM, and/or SWC were also tested (data not shown), but they did not fit the data as well as did Model 4 based on the stated model selection criteria. Some studies have reported optimal temperatures above which $R_{S}$ rates decline (Parker et al. 1983; O'Connell 1990; Fernandez et al. 2006), however analysis of Model 4 residuals indicated that the exponential relationship between $R_{S}$ and $T_{S}$ was valid even when $T_{S}$ exceeded $35^{\circ} \mathrm{C}$.

Relationships between soil respiration, soil depth, soil organic matter, and vegetation cover

Soil depth (depth to bedrock) ranged from $2.4 \mathrm{~cm}$ to $22.6 \mathrm{~cm}$. Mean $R_{s}$ rates were $2.01 \mu \mathrm{mol} \mathrm{m} \mathrm{m}^{-2} \mathrm{~s}^{-1}$ for quadrats located in shallow soil areas, $2.33 \mu \mathrm{mol} \mathrm{m} \mathrm{m}^{-2} \mathrm{~s}^{-1}$ for moderate soil depth, and $3.07 \mu \mathrm{mol} \mathrm{m} \mathrm{m}^{-2} \mathrm{~s}^{-1}$ for deep soil. Rates of $R_{s}$ differed significantly across soil depth classes, $\mathrm{F}(2,132)=3.29$, $P<0.05$, and were significantly lower for shallow soil quadrats than for those at deep soil locations $(P<0.05)$, but were not different between shallow and moderate soil depths or between moderate and deep soil depths (both $P>0.05$ ). Rates of $R_{S}$ - after having accounted for the effects of $T_{s}$, SWC, and SOM (Model 4 residuals)were significantly lower for the shallow soil depth class $(P<0.05)$ but were not different between the moderate and deep classes ( $P>0.05$; Fig. 3a).

Vegetation cover ranged from one to eight and was positively correlated with soil depth $\left(\mathrm{r}^{2}=0.46, P<0.01\right)$. Mean $R_{s}$ rates were $1.88 \mu \mathrm{mol} \mathrm{m} \mathrm{m}^{-2} \mathrm{~s}^{-1}$ for quadrats in areas of sparse vegetation, $3.00 \mu \mathrm{mol} \mathrm{m} \mathrm{m}^{-2} \mathrm{~s}^{-1}$ for moderate vegetation, and $2.99 \mu \mathrm{mol} \mathrm{m}^{-2} \mathrm{~s}^{-1}$ for thick vegetation. Rates of $R_{S}$ differed significantly across vegetation cover classes, $\mathrm{F}(2,132)=6.95, P<0.05$, as did Model 4 residuals, $\mathrm{F}(2,112)=11.22, P<0.05$. Areas of sparse vegetation had lower $R_{S}$ rates and lower Model 4 

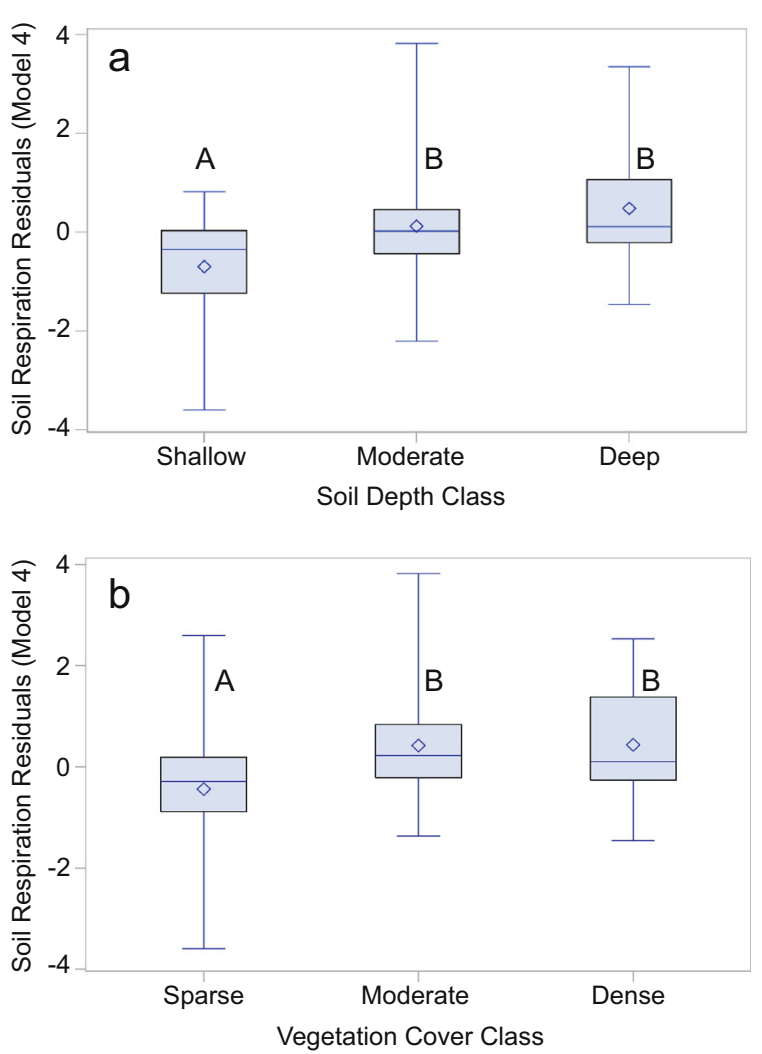

Fig. 3 Soil respiration residuals from Model 4, by (a) soil depth class and (b) vegetation cover class; box and whiskers indicate four quartiles; diamonds indicate group means; letters accompanying each bar represent significant differences $(P<0.05)$ based on ANOVA and a Tukey's post hoc test

residuals than did those in areas of moderate or dense vegetation (both $P<0.05$ ), but neither $R_{S}$ rates nor Model 4 residuals were significantly different between moderately and densely vegetated areas (both $P>0.05$; Fig. 3b). SOM (an explanatory variable in Model 4) ranged from $3.6 \%$ to $24.8 \%$, and was positively correlated with both soil depth $\left(\mathrm{r}^{2}=0.24, P<0.01\right)$ and with vegetation cover score $\left(\mathrm{r}^{2}=0.15, P<0.01\right)$. Under relatively dry conditions for this site (SWC below $15 \%$ ), the SOM effect on $R_{S}$ was increased: $d=2.01$ compared to $d=1.02 ; \mathrm{t}(113)=3.30, P<0.05$.

\section{Discussion}

Seasonal patterns of soil respiration, soil temperature, and soil moisture

In this study of limestone cedar glades, mean monthly $R_{s}$ rates across sampling locations $\left(0.7-5.3 \mu \mathrm{mol} \mathrm{m}^{-2} \mathrm{~s}^{-1}\right)$ were somewhat lower than ranges reported for deep-soil temperate grasslands such as tallgrass prairies (Bremer et al. 1998; Mielnick and Dugas 2000; Liu et al. 2002), where mean $R_{S}$ rates greater than $7.5 \mu \mathrm{mol} \mathrm{m} \mathrm{s}^{-1}$ have been observed (Craine and Wedin 2002). This difference may be attributable to edaphic and vegetation characteristics in this ecosystem (i.e. much thinner soils, patchy vegetation distribution, and high spatial variability in SOM). The $\mathrm{Q}_{10}$ value for this study (2.01) was within the range of values (1.3 to 3.3) commonly reported for in situ $R_{s}$ globally (Raich and Schlesinger 1992), and within ranges reported for mesic grasslands and semi-arid ecosystems (Xu and Qi 2001; Rey et al. 2002; Craine and Gelderman 2011).

Over the course of this study, $T_{s}$ and SWC were inversely related on a seasonal basis, reflecting regional patterns of higher precipitation and reduced evapotranspiration in winter and early spring (Baskin and Baskin 1999), a relationship that has been observed in a number of semi-arid ecosystems (Xu et al. 2004; Baldocchi et al. 2006; Almagro et al. 2009; Carbone et al. 2011; Talmon et al. 2011). While isolating the individual effects of $T_{S}$ and SWC on $R_{s}$ is problematic under such conditions (Davidson et al. 1998), our findings suggest that $R_{S}$ was largely controlled by $T_{s}$ over the course of this study. Rates of $R_{S}$ showed clear seasonal patterns, generally tracking seasonal temperature trends. The addition of SWC as an explanatory variable (Models 2 and 3 ) failed to substantially improve explanatory power over a temperature-only model (Model 1). The close association between $R_{S}$ and $T_{S}$ on a seasonal basis that we observed in limestone cedar glades has been widely observed in mesic ecosystems, including temperate mesic grasslands (Kucera and Kirkham 1971; Singh and Gupta 1977; Raich and Schlesinger 1992; Lloyd and Taylor 1994; Mielnick and Dugas 2000; Subke et al. 2006).

In this study, one clear exception occurred to the general seasonal pattern in which $R_{S}$ tracked $T_{s}$ : a reduction in $R_{S}$ under very dry conditions in late June 2012 despite high temperatures (Fig. 2). Several studies in arid and semi-arid ecosystems have also reported relatively low $R_{S}$ rates during periods of high temperature and low rainfall (Maestre and Cortina 2003; Xu et al. 2004; Baldocchi et al. 2006; Fernandez et al. 2006; Talmon et al. 2011; Cable et al. 2013). In these ecosystems, $R_{S}$ commonly tracks $\mathrm{SWC}$ on a seasonal basis and may be asynchronous with $T_{s}$, since for much of the year $R_{S}$ rates are constrained by moisture limitation (Shen 
et al. 2008; Almagro et al. 2009; Carbone et al. 2011; Rey et al. 2011). With the exception of the June 2012 sampling visit, we did not observe this type of seasonal pattern in limestone cedar glades. Across the 16 months of this study, we did not find evidence of reduced temperature effects on $R_{S}$ under relatively dry conditions (below $15 \%$ SWC).

In sharp contrast to many arid and semi-arid ecosystems, limestone cedar glade soils are also seasonally subjected to wet conditions, up to and including soil saturation (Quarterman 1950b; Norton 2010), conditions we observed most often during the winter and spring (Fig. 2b). Depending on soil porosity, very high soil moisture levels have the potential to interfere with $R_{S}$ by inhibiting the diffusion of $\mathrm{CO}_{2}$ and $\mathrm{O}_{2}$ (Linn and Doran 1984; Hui and Luo 2004; Davidson and Janssens 2006; Almagro et al. 2009; Butler et al. 2011). We observed lower $R_{S}$ rates under relatively wet conditions (SWC above $40 \%$ ) in limestone cedar glades, however, residuals analysis indicated that these wet soil conditions did not suppress $R_{S}$ independently from cooccurring low temperatures.

Influences of soil organic matter, soil depth, and vegetation on soil respiration

In this study of limestone cedar glades, SOM exhibited considerable spatial variability and was an important control on $R_{s}$. We observed a roughly seven-fold difference between maximum and minimum SOM values, and found that the incorporation of SOM (Model 4) dramatically improved model performance relative to a model based only on $T_{s}$ and SWC (Model 2). Our findings in limestone cedar glades are consistent with studies showing SOM and the soil carbon pool size to be important controls on $R_{S}$ in grasslands (Thomson et al., 2010; Balogh et al., 2011) and in arid and semi-arid ecosystems (Conant et al. 2000; Sponseller 2007; Talmon et al. 2011). Although we did not measure soil organic carbon or the labile carbon fraction directly, the strong positive relationship we observed between $R_{S}$ rates and $\mathrm{SOM}$ was not surprising, given that $R_{S}$ can often be predicted effectively using first-order kinetic models (Parton et al. 1988; Zak et al. 1999). This finding supports assertions that $\mathrm{Q}_{10}$ estimates can be improved by incorporating substrate-limitation effects on the temperature sensitivity of decomposition (Davidson and Janssens 2006), as our $\mathrm{Q}_{10}$ estimate would have been
$33 \%$ lower had we failed to incorporate SOM as a model variable.

We observed an increased effect of SOM on $R_{S}$ under relatively dry conditions for this site (SWC below $15 \%)$. Although we did not partition $R_{S}$ into autotrophic versus heterotrophic components, this finding is consistent with a hypothesis of increased heterotrophic relative to autotrophic respiration during senescence periods when root-growth respiration is restricted by moisture limitation (Baldocchi et al. 2006; Butler et al. 2011). Under such a scenario, heterotrophic respiration sustained by existing carbon substrate pools might assume greater relative importance to soil $\mathrm{CO}_{2}$ efflux totals, resulting in $R_{s}$ patterns that correspond more closely to spatial variability in SOM. To evaluate this hypothesis, future research efforts in limestone cedar glades would need to partition the components of soil $\mathrm{CO}_{2}$ efflux and compare the relative contributions of these components - as well as their individual relationships to soil carbon pool size - to measurements of root proliferation under various soil moisture conditions.

Results from this study indicate that spatial heterogeneity in soil depth and vegetation cover influenced $R_{S}$ in limestone cedar glades. Shallow soil and sparse vegetation were both associated with reduced $R_{S}$ levels, and residuals analysis showed these relationships existed even after accounting for the effects of $T_{s}$, SWC, and SOM (Fig. 3). We did not attempt to isolate the effects of soil depth from those of vegetation cover since, as noted by Risch and Frank (2006), effects on $R_{S}$ of topographic gradients (e.g. soil depth and landscape position) may be difficult to separate from those of the biotic gradients they influence (e.g., vegetation cover). Indeed, vegetation patterns are strongly related to soil depth in limestone cedar glades (Freeman 1933; Quarterman 1950a; Norton 2010). It is noteworthy that our finding of depressed $R_{S}$ occurred at soil depths below $5 \mathrm{~cm}$, since analysis of botanical data from this ecosystem previously identified the same soil depth threshold to delineate ecological zones (Quarterman 1973; 1989; Quarterman et al. 1993) and primary plant community types (Somers et al. 1986). It should also be noted that our inability to measure $R_{S}$ in zones of extremely thin soil (below $2 \mathrm{~cm}$ soil depth) suggests that the true range of $R_{S}$ rates in limestone cedar glades-including zones of exposed bedrock and their peripheries - likely includes lower $R_{S}$ rates than were observed in this study.

The significant positive relationship between vegetation cover and $R_{S}$ in this study is consistent with 
observations from temperate grasslands (Craine and Wedin 2002; Flanagan and Johnson 2005; Risch and Frank 2006; Thomson et al. 2010) and arid and semiarid ecosystems (Maestre and Cortina 2003; Sponseller 2007; Cable et al. 2008; Talmon et al. 2011). In addition to direct contributions through autotrophic respiration, plants can facilitate heterotrophic respiration by providing carbon substrates in the form of litter and root exudates, thus concentrating resources and associated microbes in rhizosphere soil (Sponseller 2007; Thomson et al. 2010). Plants also affect $R_{s}$ by influencing the microclimates of their surroundings through effects such as transpiration, rainfall interception, and shading (Raich and Tufekciogul 2000; Almagro et al. 2009). Future research could seek to quantify and partition these effects, as certain zones and ecotones in cedar glades may be vulnerable to vegetation changes such as woody encroachment (Sutter et al. 2011), which can alter $R_{S}$ dynamics in grasslands (Eler et al. 2013). Future research could also examine $R_{S}$ across vascular plant associations, e.g. grass-dominated versus forbdominated communities, and unique assemblages of xerophytic and hydrophytic vegetation (Quarterman 1950a; Norton 2010).

\section{Conclusions}

This was the first reported study of $R_{S}$ in limestone cedar glades. In this rock outcrop ecosystem, $\mathrm{Q}_{10}$ was within ranges reported for temperate mesic grasslands, however, $R_{s}$ rates were somewhat lower than in several studies of tallgrass prairies. Cedar glades are distinguishable from such deep-soil grasslands by having zones of exposed bedrock, extremely thin soils, patchy vegetation distribution, and seasonal fluctuation between both hydrologic extremes. In several respects, the seasonal controls on $R_{S}$ in limestone cedar glades resembled those in temperate mesic grasslands more than those in arid and semi-arid ecosystems. At a seasonal level, $R_{s}$ generally tracked $T_{S}$ for most of the year, and although extreme soil moisture conditions (both xeric and saturated) were occasionally observed, apparent differences in $R_{s}$ under relatively dry or wet conditions did not exist independently from temperature effects. Although we observed depressed $R_{S}$ during one sampling visit under summer drought conditions, we did not detect a shift in the temperature sensitivity of $R_{s}$ when SWC was less than $15 \%$. SOM was highly variable spatially and an important control on $R_{s}$, such that incorporating its effects dramatically improved model performance over models based only on $T_{S}$ and SWC. Shallow soils and sparse vegetation cover-defining features of certain ecological zones within this ecosystem-were associated with reduced rates of $R_{s}$. Further investigations of soil respiration patterns in limestone cedar glades could employ intensive sampling under xeric conditions, partition heterotrophic versus autotrophic respiration, and examine $R_{S}$ relationships to vegetation dynamics (e.g. woody encroachment).

Acknowledgments The authors acknowledge the National Park Service, Department of the Interior, USA, for financial support of the research project (NPS study number STRI-00025) and Tennessee State University (Nashville, Tennessee, USA) for the use of laboratory facilities. The LI-6400 XT Portable Photosynthesis System was supported by the National Science Foundation (0923371) and the LEEF Award from Li-Cor Inc. The authors wish to thank the staff at Stones River National Battlefield for logistical support, and Dr. William Wolfe, Dr. Thomas Byl, and anonymous reviewers for their suggestions on the manuscript. Any use of trade, firm, or product names is for descriptive purposes only and does not imply endorsement by the U.S. Government.

Open Access This article is distributed under the terms of the Creative Commons Attribution License which permits any use, distribution, and reproduction in any medium, provided the original author(s) and the source are credited.

\section{References}

Adams D, Walck J, Howard R, Milberg P (2012) Forest composition and structure on glade-forming limestones in Middle Tennessee. Castanea 77:335-347

Almagro M, López J, Querejeta J, Martinez-Mena M (2009) Temperature dependence of soil $\mathrm{CO}_{2}$ efflux is strongly modulated by seasonal patterns of moisture availability in a Mediterranean ecosystem. Soil Biol Biochem 41:594-605

Amundson R, Chadwick O, Sowers J (1989) A comparison of soil climate and biological activity along an elevation gradient in the eastern Mojave Desert. Oecologia 80:395-400

Anderson R, Fralish J, Baskin J (1999) Introduction. In: Anderson R, Fralish J, Baskin J (eds) Savannas, barrens, and rock outcrop plant communities of North America. Cambridge University Press, New York, pp 1-4

Baldocchi D, Tang J, Xu L (2006) How switches and lags in biophysical regulators affect spatial-temporal variation of soil respiration in an oak-grass savanna. J Geophys Res 111, G02008

Balogh J, Pintér K, Fóti S et al (2011) Dependence of soil respiration on soil moisture, clay content, soil organic matter, and $\mathrm{CO}_{2}$ uptake in dry grasslands. Soil Biol Biochem 43:10061013

Baskin J, Baskin C (1999) Cedar glades of the southeastern United States. In: Anderson R, Fralish J, Baskin J (eds) Savannas, 
barrens, and rock outcrop plant communities of North America. Cambridge University Press, New York, pp 206-219

Baskin J, Baskin C (2003) The vascular flora of cedar glades of the southeastern United States and its phytogeographical relationships. J Torrey Bot Soc 130:101-118

Baskin J, Baskin C (1988) Endemism in rock outcrop plant communities of unglaciated eastern United States: an evaluation of the roles of the edaphic, genetic and light factors. J Biogeogr 15:829-840

Baskin J, Baskin C (1985) Photosynthetic pathway in 14 southeastern cedar glade endemics, as revealed by leaf anatomy. Am Midl Nat 114:205-208

Baskin J, Baskin C (1989) Cedar glade endemics in Tennessee, and a review of their autecology. J Tenn Acad Sci 64:6374

Baskin J, Baskin C, Lawless P (2007a) Calcareous rock outcrop vegetation of eastern North America (exclusive of the Nashville Basin), with particular reference to use of the term "Cedar Glades". Bot Rev 73:303-325

Baskin J, Baskin C, Quarterman E (2007b) Flow diagrams for plant succession in the Middle Tennessee cedar glades. J Bot Res Inst Texas 1:1131-1140

Baskin J, Webb D, Baskin C (1995) A floristic plant ecology study of the limestone glades of northern Alabama. Bulletin of the Torrey Botanical Club 122:226-242

Bond-Lamberty B, Thomson A (2010) Temperature-associated increases in the global soil respiration record. Nature 464: 579-82

Bremer D, Ham J, Owensby C, Knapp A (1998) Responses of soil respiration to clipping and grazing in a tallgrass prairie. $\mathrm{J}$ Environ Qual 27:1539-1548

Burnham K, Anderson D (2002) Model selection and multimodel inference: a practical information-theoretic approach, 2nd edn. Springer, New York

Butler A, Meir P, Saiz G et al (2011) Annual variation in soil respiration and its component parts in two structurally contrasting woody savannas in Central Brazil. Plant Soil 352: $129-142$

Cable J, Ogle K, Barron-Gafford G et al (2013) Antecedent conditions influence soil respiration differences in shrub and grass patches. Ecosystems 16:1230-1247

Cable J, Ogle K, Williams D et al (2008) Soil texture drives responses of soil respiration to precipitation pulses in the Sonoran Desert: Implications for climate change. Ecosystems 11:961-979

Carbone M, Still C, Ambrose A (2011) Seasonal and episodic moisture controls on plant and microbial contributions to soil respiration. Oecologia 167:265-278

Conant R, Klopatek J, Klopatek C (2000) Environmental factors controlling soil respiration in three semiarid ecosystems. Soil Sci Soc Am J 64:383-390

Craine J, Wedin D (2002) Determinants of growing season soil $\mathrm{CO}_{2}$ flux in a Minnesota grassland. Biogeochemistry 59: 303-313

Craine J, Gelderman T (2011) Soil moisture controls on temperature sensitivity of soil organic carbon decomposition for a mesic grassland. Soil Biol Biochem 43: 455-457

Davidson E, Belk E, Boone R (1998) Soil water content and temperature as independent or confounded factors controlling soil respiration in a temperate mixed hardwood forest. Glob Chang Biol 4:217-227

Davidson E, Janssens I (2006) Temperature sensitivity of soil carbon decomposition and feedbacks to climate change. Nature 440:165-73

Davies B (1973) Loss-on-ignition as an estimate of soil organic matter. Soil Sci Soc Am J 38:150-151

Deng Q, Hui D, Zhang D et al (2012) Effects of precipitation increase on soil respiration: a three-year field experiment in subtropical forests in China. PLoS One 7:e41493

Dixon R, Brown S, Houghton R et al (1994) Carbon pools and flux of global forest ecosystems. Science 263:185-191

Fenneman N (1938) Physiography of the Eastern United States. MacGraw-Hill, New York

Fernandez D, Neff J, Belnap J, Reynolds R (2006) Soil respiration in the cold desert environment of the Colorado Plateau (USA): Abiotic regulators and thresholds. Biogeochemistry 78:247-265

Flanagan L, Johnson B (2005) Interacting effects of temperature, soil moisture and plant biomass production on ecosystem respiration in a northern temperate grassland. Agric For Meteorol 130:237-253

Freeman C (1933) Ecology of the cedar glade vegetation near Nashville Tennessee. J Tenn Acad Sci 8:143-228

Hui D, Luo Y (2004) Evaluation of soil $\mathrm{CO}_{2}$ production and transport in Duke Forest using a process-based modeling approach. Glob Biogeochem Cycles 18, GB4029

Jarvis P, Rey A, Petsikos C et al (2007) Drying and wetting of Mediterranean soils stimulates decomposition and carbon dioxide emission: the "Birch effect". Tree Physiol 27:929-40

Jia B, Zhou G, Wang Y et al (2006) Effects of temperature and soil water-content on soil respiration of grazed and ungrazed Leymus chinensis steppes, Inner Mongolia. J Arid Environ 67:60-76

Joffre R, Ourcival J, Rambal S, Rocheteau A (2003) The key-role of topsoil moisture on $\mathrm{CO}_{2}$ efflux from a Mediterranean Quercus ilex forest. Ann For Sci 60:519-526

Kucera C, Kirkham D (1971) Soil respiration studies in tallgrass prairie in Missouri. Ecology 52:912-915

Lawless P, Baskin J, Baskin C (2006) Xeric limestone prairies of eastern United States: review and synthesis. Bot Rev 72:235272

Linn D, Doran J (1984) Effect of water-filled pore space on carbon dioxide and nitrous oxide production in tilled and nontilled soils. Soil Sci Soc Am J 48:1267-1272

Liu W, Zhang Z, Wan S (2009) Predominant role of water in regulating soil and microbial respiration and their responses to climate change in a semiarid grassland. Glob Chang Biol 15:184-195

Liu X, Wan S, Su B et al (2002) Response of soil $\mathrm{CO}_{2}$ efflux to water manipulation in a tallgrass prairie ecosystem. Plant Soil 240:213-223

Lloyd J, Taylor J (1994) On the temperature dependence of soil respiration. Funct Ecol 8:315-323

Luo Y, Wan S, Hui D, Wallace L (2001) Acclimatization of soil respiration to warming in a tall grass prairie. Nature 413: 622-625

Luo Y, Zhou X (2006) Soil Respiration and the Environment. Academic Press / Elsevier, San Diego, CA 
Maestre F, Cortina J (2003) Small-scale spatial variation in soil $\mathrm{CO}_{2}$ efflux in a Mediterranean semiarid steppe. Appl Soil Ecol 23:199-209

Mahr W, Mathis P (1981) Foliose and fruticose lichens of the cedar glades in Stones River National Battlefield Park (Rutherford County, Tennessee). J Tenn AcadSci 56:66-67

Martin E, Sharp R (1983) Soil protozoa from a cedar glade in Rutherford County, Tennessee. J Tenn Acad Sci 58:31-36

Mielnick P, Dugas W (2000) Soil $\mathrm{CO}_{2}$ flux in a tallgrass prairie. Soil Biol Biochem 32:221-228

Morris L, Walck J, Hidayati S (2002) Reproduction of the invasive Ligustrum sinense and native Forestiera ligustrina (Oleaceae): implications for the invasion and persistence of a nonnative shrub. Int J Plant Sci 163:1001-1010

Motulsky H, Ransnas L (1987) Fitting curves to data using nonlinear regression: a practical and nonmathematical review. FASEB J 1:365-374

Munson S, Benton T, Lauenroth W, Burke I (2009) Soil carbon flux following pulse precipitation events in the shortgrass steppe. Ecol Res 25:205-211

National Climatic Data Center (2014) Annual Climatological Summaries, 2010-2014. Asheville, NC

Nordman C (2004) Vascular plant community classification for Stones River National Battlefield. NatureServe, Durham, NC

Norton K (2010) A Floristic Ecology Study of Seasonally Wet Limestone Cedar Glades of Tennessee and Kentucky. Masters thesis, Austin Peay State University.

Noss R (2013) Forgotten Grasslands of the South. Island Press, Washington, DC

O'Connell A (1990) Microbial decomposition (respiration) of litter in eucalypt forests of south-western Australia: an empirical model based on laboratory incubations. Soil Biol Biochem 22:153-160

Parker L, Miller J, Steinberger Y, Whitford W (1983) Soil respiration in a Chihuahuan desert rangeland. Soil Biol Biochem 15:303-309

Parton W, Stewart J, Cole C (1988) Dynamics of C, N, P and S in grassland soils: a model. Biogeochemistry 5:109-131

Quarterman E (1950a) Major plant communities of Tennessee cedar glades. Ecology 31:234-254

Quarterman E (1950b) Ecology of cedar glades I Distribution of glade flora in Tennessee. Bulletin of the Torrey Botanical Club 77:1-9

Quarterman E (1989) Structure and dynamics of the limestone cedar glade communities in Tennessee. J Tenn Acad Sci 64: $155-158$

Quarterman E (1973) Allelopathy in cedar glade plant communities. J Tenn Acad Sci 48:147-150

Quarterman E, Burbanck M, Shure D (1993) Rock outcrop communities: limestone, sandstone, and granite. In: Martin W, Boyce S, Echternacht A (eds) Biodiversity of the Southeastern United States: Upland Terrestrial Communities. Wiley, New York, pp 35-86

Raich J, Schlesinger W (1992) The global carbon dioxide flux in soil respiration and its relationship to vegetation and climate. Tellus 44:81-99

Raich J, Tufekciogul A (2000) Vegetation and soil respiration: correlations and controls. Biogeochemistry 48:71-90
Reichstein M, Tenhunen J, Roupsard O et al (2002) Severe drought effects on ecosystem $\mathrm{CO}_{2}$ and $\mathrm{H}_{2} \mathrm{O}$ fluxes at three Mediterranean evergreen sites: revision of current hypotheses? Glob Chang Biol 8:999-1017

Rey A, Pegoraro E, Oyonarte C et al (2011) Impact of land degradation on soil respiration in a steppe (Stipa tenacissima L.) semi-arid ecosystem in the SE of Spain. Soil Biol Biochem 43:393-403

Rey A, Pegoraro E, Tedeschi V (2002) Annual variation in soil respiration and its components in a coppice oak forest in Central Italy. Glob Chang Biol 8:851-866

Rey A, Petsikos C, Jarvis P, Grace J (2005) Effect of temperature and moisture on rates of carbon mineralization in a Mediterranean oak forest soil under controlled and field conditions. Eur J Soil Sci 56:589-599

Risch A, Frank D (2006) Carbon dioxide fluxes in a spatially and temporally heterogeneous temperate grassland. Oecologia 147:291-302

Schimel D (1995) Terrestrial ecosystems and the carbon cycle. Glob Chang Biol 1:77-91

Schwinning S, Sala O, Loik M, Ehleringer J (2004) Thresholds, memory, and seasonality: understanding pulse dynamics in arid/semi-arid ecosystems. Oecologia 141:191-3

Shen W, Jenerette G, Hui D et al (2008) Effects of changing precipitation regimes on dryland soil respiration and $\mathrm{C}$ pool dynamics at rainfall event, seasonal and interannual scales. J Geophys Res 113, G03024

Singh J, Gupta S (1977) Plant decomposition and soil respiration in terrestrial ecosystems. Bot Rev 43:449-528

Somers P, Smith L, Hamel P, Bridges E (1986) Preliminary analyses of plant communities and seasonal changes in cedar glades of Middle Tennessee. Association of Southeastern Biologists Bulletin 33:178-192

Sponseller R (2007) Precipitation pulses and soil $\mathrm{CO}_{2}$ flux in a Sonoran Desert ecosystem. Glob Chang Biol 13:426-436

Subke J, Inglima I, Cotrufo F (2006) Trends and methodological impacts in soil $\mathrm{CO}_{2}$ efflux partitioning: A metaanalytical review. Glob Chang Biol 12:921-943

Talmon Y, Sternberg M, Grünzweig J (2011) Impact of rainfall manipulations and biotic controls on soil respiration in Mediterranean and desert ecosystems along an aridity gradient. Glob Chang Biol 17:1108-1118

Tang J, Baldocchi D (2005) Spatial-temporal variation in soil respiration in an oak-grass savanna ecosystem in California and its partitioning into autotrophic and heterotrophic components. Biogeochemistry 73:183-207

Thomson B, Ostle N, McNamara N et al (2010) Vegetation affects the relative abundances of dominant soil bacterial taxa and soil respiration rates in an upland grassland soil. Microb Ecol 59:335-43

Topp G, Ferre P (2002) The Soil Solution Phase, 3.1, Water Content. In: Carter M, Gregorich E (eds) Methods of Soil Analysis, Part 4: Physical Methods. CRC Press, Boca Raton, FL

Vargas R, Allen M (2008) Environmental controls and the influence of vegetation type, fine roots and rhizomorphs on diel and seasonal variation in soil respiration. New Phytol 179: 460-471

Wildung R, Garland T, Buschbom R (1975) The interdependent effects of soil temperature and water content on soil respiration rate and plant root decomposition in arid grassland soils. Soil Biol Biochem 7:373-378 
Xu L, Baldocchi D, Tang J (2004) How soil moisture, rain pulses, and growth alter the response of ecosystem respiration to temperature. Glob Biogeochem Cycles 18, GB4002

$\mathrm{Xu}$ M, Qi Y (2001) Soil-surface $\mathrm{CO}_{2}$ efflux and its spatial and temporal variations in a young ponderosa pine plantation in northern California. Glob Chang Biol 7:667-677
Zak D, Holmes W, MacDonald N, Pregitzer K (1999) Soil temperature, matric potential, and the kinetics of microbial respiration and nitrogen mineralization. Soil Sci Soc Am J 63: 575-584

Zhang L, Chen Y, Li W, Zhao R (2009) Abiotic regulators of soil respiration in desert ecosystems. Environ Geol 57:1855-1864 